Tourism 2020, 30/2

\author{
Sławoj Tanaś \\ https://orcid.org/0000-0003-3325-2645 \\ University of Lodz \\ Faculty of Geographical Sciences \\ Institute of Urban Geography, Tourism and Geoinformation \\ slawoj.tanas@geo.uni.lodz.pl
}

\title{
THE PROFANE SPHERE OF ALL SAINTS' DAY AND THE SOCIAL ASPECTS OF CEMETERIES
}

\begin{abstract}
The modern pop-culturization of All Saints' Day has encouraged the author to explore the profane sphere of this festival, using selected examples from Łódź cemeteries, as well as to write a short comparative description of a Latin American festival honouring the dead celebrated in early November. In the $20^{\text {th }}$ century, visiting cemeteries in Poland on $1^{\text {st }}$ November acquired some attributes of recreation and cultural tourism, visible in the atmosphere of a country fair and the ludic character of the cemetery surroundings, as well as the visitors' commemorative, contemplative and cognitive motivations. Due to cultural changes, All Saints' Day is increasingly perceived as a tourist event or even a cultural tourism product. The article presents a comparative description of the All Saints' Day celebrations in Poland and the Day of the Dead in Latin America, and an analysis of visitors at selected Łódź cemeteries along with a description of the cemetery surroundings on $1^{\text {st }}$ November 2019. The author has used unpublished research results from 2004, as well as discussing the secular and recreational aspects of All Saints' Day.
\end{abstract}

Keywords: All Saints' Day, Day of the Dead, Łódź, Latin America, cemetery.

\section{INTRODUCTION}

In European, Central- and South-American cultures, $1^{\text {st }}$ and $2^{\text {nd }}$ November are a time when people visit the graves of Saints and the beatified, as well as their own ancestors, family members and close friends. The purpose of visiting cemeteries at the end of October and the beginning of November is to fulfil commemorative and religious needs. Festivals in honour of the dead originated mostly from religion, rituality, faith in an afterlife and, which is very important from the geographical point of view, cultural syncretism.

All Saints' Day and All Souls' Day (Zaduszki) celebrations in Europe belong to the religious sphere but have always included folk and secular components as well, observed in beliefs, rituals and social traditions (Ariés, 1989; Kolbuszewski, 1996).

In the Middle Ages, European cemeteries were located close to churches and brought together local people around graves (remembering the deceased, faith in an afterlife), rites (processions, prayers, ceremonials) and events (trade, fairs, courts, executions). The cultural revolution that took place at the turn of the 19th century, which included changes in cemetery location and organization, placed the deceased person in the centre of social life again. From then onwards, he or she was to remain close to the living, not only through prayer and memory, but above all through the grave, situated at a nicely located cemetery, surrounded by greenery (cemetery-park) and art (cemetery - a sepulchral sculpture gallery). A consequence of these changes was the social redefinition of All Saints' and All Souls' Days, earlier less popular in urban areas but very common in rural ones where they had a strictly religious and ludic character. All Saints' Day became a time for visiting individual graves according to established ceremonial of a fixed but geographically diversified cultural code, itself undergoing regular modifications as a result of socio-economic transformations. Thus, the changing way of living in an urban area had a direct influence on the social dimension of All Saints' Day making those interested aware of the cultural and religious sources of the tradition in secular cemeteries. The sphere of profanum started to interfere with the sacrum of tradition and rituality with cultural development (see also: Eliade, 1996; Jackowski, 2003).

The festival in honour of the dead, celebrated in early November in the countries of Latin America, displays 
a number of characteristic features: at cemeteries and around them, picnics are organized, food and drink are enjoyed, while graves decorated with flowers and candles are common practice. Moreover, parades are organized of people dressed up as Death in a colonial style costume with a characteristic hat. It is a tradition to construct and fly colourful kites which connect the living to the souls of the deceased. Even dancing parties are held. As regards the culinary aspect of the festival, traditional cakes are enjoyed, including sugar sculls with icing. These traditions, so different from those present in European cultures, are strictly connected with church ceremonial, Holy Mass and prayer, as well as the memory of the dead. The different character of the Day of the Dead in Latin America has encouraged the inhabitants of the United States and Europe to travel, especially to Mexico, where the carnival-like October/ November celebrations to honour the dead have become a well-recognized tourism product.

These were the reasons for the author's choice of a geographical area with which he compared a Polish festival in honour of the deceased, which not only has the features of a religious festival, but is also full of ludic elements used in a recreational manner. The rituals and traditions have a strongly syncretic character, combining Christian traditions with pre-Columbian beliefs, just like All Saints' and All Souls' Days in Europe combine Christian traditions with pagan rituals (Arias, 1989; Brandes, 1998b).

All Saints' Day and All Souls' Day in Poland have a slightly different dimension than the Mexican Day of the Dead. On these days, the people who visit graves are immersed in deep thought and prayer. The atmosphere of a carnival and festivity, so typical of Latin America, is missing. Meals are eaten together during family dinners at homes and not at cemeteries. In Poland, nobody flies kites, organizes street parades or displays symbols of death, there is no tradition of preparing cakes or dishes for the dead. However, in some places, special sweets are sold: pańska skórka in Warsaw, turecki miodek in Kraków and szczypki in the Lublin region.

Elements observed in both festivals in honour of the dead include cleaning graves and decorating them with flowers, burning candles for the souls of the dead and the visiting of graves by large numbers of people. The crowds coming to cemeteries, the decorative character of the graves and the special evening atmosphere created at candle-lit cemeteries has turned All Saints' Day in Poland (like the Day of the Dead in Mexico) into a tourism product among the important national and religious festivals promoted by the Polish Tourism Organization.

During the transformation period in Poland after 1989 , attempts to return to the mode of celebration practiced earlier in the 20th century were made. The country fair atmosphere and ludic character of the stalls set up around cemeteries, food stands, balloons, ice-creams, candy floss and pretzels, and toys for children, pointed to the secular character of its celebration among family and friends. This is of course disapproved of by the Catholic Church and a part of the conservative society, but the Generation ' $Z$ ' of today treat All Saints' Day differently in a pop-cultural way, increasingly combining it with the night before November $1^{\text {st }}$ - the secular, carnival-like Halloween, which has gained a commercial character.

\section{THE CEMETERY AS A VENUE}

People and the culture they create are strongly interconnected, determining the character of cognitive and recreational spaces and a site which displays the attributes of both is a cemetery (Stasiak, Tanaś, 2005).

In $18^{\text {th }}$ and $19^{\text {th }}$ century Europe, guided by the Enlightenment and later ideas, those who organized cemeteries in cities had to consider not only their practical aspect (the need to bury dead bodies) or religious motivations, but also the inhabitants' needs that resulted from a growing amount of leisure time ${ }^{1}$. A cemetery became a place where people could rest from the bustle of the city and recover physical and mental strength, as well as a place of Romantic contemplation and aesthetic and emotional experience. Similar to the parks and gardens set up at that time, cemeteries became urban enclaves, suitable for walks and other purposes quite different from those originally intended.

The cemetery is a collection of graves and this is the main purpose for visits. The grave is a social and emotional space created around the deceased which has its own conventional symbolism of the dead person's home after death, composed of a number of external attributes such as form, sculpture, epigraphs or plant decoration. Thus, the cemetery is a particular cultural text (Kolbuszewski, 1985). Its character and its semantic expression are defined through its cultural-emotional features and interpretation which depend on cultural roots, and may explain to what extent it constitutes a link between the present and the past, between the living and the dead.

In the second half of the $19^{\text {th }}$ century, a fashion started for the cult of the tomb which changed the society's attitude to the grave and the cemetery. The grave stopped being anonymous and the cemetery became a text of artistic culture, an object worthy of exploration as well as for literary, academic and travel description (Ariés, 1989). This generated the concept of a cemetery space which would facilitate practicing the cult of the dead and defining one of the basic elements of a sense of citizenship as well. This idea was propagated by the Catholic Church which, after many centuries of remembering 
the deceased only in a prayer at a shrine, returned to the cult of the individual dead and to the practice of visiting their graves. This was supported by the Catholic Church which returned to the cult of the dead, and the individualization and cult of the grave, after many centuries of honouring a dead person exclusively through prayer.

Thus, in the $19^{\text {th }}$ century, the cemetery became a place of a new ritual through the duty of regularly visiting graves. Due to the new organization, burial space became a kind of a memorial park intended for individual and family visits, an open-air museum and a place fostering thoughtfulness and reflection. In Britain France and the United States, the idea of 'cemetery gardens' and 'cemetery parks', designed with visitors in mind, were to combine landscape assets including greenery and architecture, with social assets such as history, tradition, art and religion. The form of a park or garden was to be a proper background for reflection and memories of the deceased, a place for mourning after losing someone close, supportive psychotherapy and encouraging regeneration in a sympathetic environment. The urban cemetery became an alternative to a park - a green area, particularly significant in the rapidly growing urban centres of the $19^{\text {th }}$ century when they were undergoing uncontrollable industrialization (Długozima, 2011; Tanaś, 2008). The cemetery was not supposed to be a place of medieval, chaotic burial, but a space of remembrance, calming thoughts and emotions, a space of regeneration, and a component of recreation. Due to the popularity of sepulchral sculpture, the cemetery also became an 'art gallery', i.e. a place of aesthetic experience where artistic trends were created.

The cemetery is a ritual space where religious and secular, burial and commemorative ceremonies are an important component. Depending on established cultural norms, cemeteries are venues for events and celebrations which attract local communities at given times during the year, and tourists who want to witness unusual events. These events are mostly burial ceremonies, geographically diversified as regards their character and rituals, as well as commemorative festivals such as the European All Saints' and All Souls' Days, the Mexican Day of the Dead or the Japanese festival called Bon, as well as Easter festivities including the tradition of visiting the graves of the closest family and friends, similar to visiting Christ's sepulchre, or the tradition of visiting graves during Pentecost commonly practiced in the Eastern Orthodox Church.

Due to its natural and architectonic decor, the cemetery can be a venue for artistic events such as classical music concerts in memory of certain individuals who have passed away (e.g. that held at the Central Cemetery in Szczecin, the Ohlsdorf cemetery in Hamburg, or the Skogskyrkogården cemetery in Stockholm).
Religious and secular events organized at cemeteries have become the aim of tourist trips, and are often promoted as tourist attractions or even tourism products. Is this a sign of modern times? Certainly not - in the Middle Ages, and in the centuries which followed, the public gathered at graveyards next to churches where religious and secular festivals were celebrated. The graveyard was a place for public trials, community meetings, regional council assemblies, or where pilgrims and participants of parades and processions could pause for rest. It was also a place of interrogation, torture and execution. During festivals, the graveyard and its surroundings functioned as a market place where fairs were organized.

The graveyard, similar to the church, was, and in a sense still is, an asylum. With time, this function transformed the graveyard into a public meeting site and a place used by the living - it was a refuge for runaways and the homeless who lived in ossuaries or in small, rickety huts (Ariés, 1989). In Latin America, there are still sepulchres adapted to the needs of their inhabitants, especially in the poor districts of large cities, such as the Northern Cemetery in Manila (the Philippines). Situated close to the church, the graveyard often performed the function of a market place, busy and noisy both in the city and the countryside because the church building (the centre of urban and rural life) sometimes could not hold all the local believers. Hence, the graveyard located next to the church was used in a variety of ways for instance, beautifully decorated for the occasion, it was used for Palm Sunday or Corpus Christi processions.

The Church disapproved of these practices but, as for burials in churches, the rules it imposed were regularly broken. After all, in the Middle Ages, the graveyard belonged to the community and such practices were not considered reprehensible. In Poland, fairs, meetings, rallies, or even loud parties (e.g. on All Saints' Day) were common despite the regulations introduced by the Church (synods banned the organization of secular events in graveyards).

The graveyard was and still is an active and significant public space, despite the fact that from the $16^{\text {th }}$ century, its function as a public place was gradually shifted to an adjacent or market square. Looking at contemporary Polish cemeteries at the time of church festivals, including All Saints' Day, various ways of using cemetery surroundings can be found. There are stalls with toys or food, people taking a walk, evening strolls and 'playing at ghosts'. Since the Middle Ages, excepting the period from the $16^{\text {th }}$ to $18^{\text {th }}$ century, the cemetery has been not only a sacred space, but also a public, profane, cognitive and, consequently, recreation and tourism space (Tanaś, 2008).

Along with the European colonization of Latin America, and the Christian canon imposed on the 
indigenous population, the native residents of cities founded by Europeans gradually adopted European rituality regarding the dead and the ways of organizing cemeteries, while retaining elements of Indian traditions at the same time. Strongly rooted in the indigenous community, the beliefs made the sacred sphere, including cemeteries, a space of cultural syncretism. In modern times in Latin America, a cultural melting pot can be seen, a conglomerate of Indian and Christian symbolism. The distinctiveness and, at the same time, affinity to European culture were the reason why Latin American cemeteries have become a cultural tourism destination (Cano, Mysyk, 2004; Miller, Space, 2006).

\section{NOVEMBER FESTIVALS IN HONOUR OF THE DEAD}

All Saints' Day is a Christian festival in honour of all the saints and all those who have been redeemed and now live in heaven. It started to be celebrated in the $4^{\text {th }}$ century when on the first Sunday after Pentecost, a festival was celebrated dedicated to all martyrs. In the Eastern Orthodox Church, the tradition of remembering saints on this day is still continued. In Polish folk tradition, Pentecost, celebrated 50 days after Easter Sunday, is dedicated to the memory of dead ancestors (especially in the Eastern Orthodox Church). In 609, Pope Boniface IV brought the idea of the festival into life when he dedicated the ancient Roman shrine in honour of all gods (the Pantheon) to the Virgin Mary and the holy martyrs, and the main celebrations were set for $13^{\text {th }}$ May. In 835, Pope Gregory IV established another festival in honour of the saints celebrated on $1^{\text {st }}$ November. The idea of All Souls' Day, dedicated to the memory of the faithful who died and suffered in Purgatory, was conceived by Abbot Odilon from Cluny, who ordered in 998 that all monasteries in the Clunaic tradition must hold an Office for the dead. With time, the festival was adopted in the whole of the western Church and celebrated on $2^{\text {nd }}$ November. At present, All Saints' Day in the Catholic Church is in fact strictly connected with All Souls' Day (Kupisiński, 2007).

In the Polish tradition, All Saints' and All Souls' Days are a time for reflection and remembering the deceased. However, the custom of visiting graves has ecumenical and commercial features as well. Poles travel long distances to return for a short time to their place of birth, or to places related to the stories of their lives, family, friends or nation.

$1^{\text {st }}$ and $2^{\text {nd }}$ November in Latin America, when the Day (or Festival) of the Dead (Dia de los Muertos, Día de los Difuntos, Fiesta de las Natitas, Fet Gede, Arawng mga Patay) is celebrated, are a syncretic combination of All Saints' and All Souls' Days with pre-Columbian rituals in honour of the ancestors. In Mexico, Guatemala, Peru, Bolivia, Haiti or the Philippines, they have distinctive features of a carnival where the cemetery is a place of joyful family meetings with the deceased, however retaining the atmosphere of the afterlife mystery (Jaszczak, Dreksler, 2013).

Celebrations in Latin America vary, depending on the country and region, but they all include some practices such as renovating, cleaning or repainting family graves, gravestones and crosses, decorating them with flowers and candles, building symbolic altars at home or on the graves, preparing special meals and drinks, praying for the souls of the dead and participating in Holy Mass. In native regions of Latin America, such as southern Mexico, territories inhabited by Mayans, or the Andes regions, families take part in complicated rituals at cemeteries, which involve singing, dancing, picnics, leaving food for the dead on, by or inside graves, a vigil for the spirits and ritual games. In Guatemala, people fly kites to welcome the souls of the dead. Many native inhabitants arrange special altars dedicated to the deceased, decorate them with flowers, candles, incense and souvenirs, prepare special dishes. Mexican cakes in the shape of a scull, produced from white sugar and ornamented with icing, have become a symbol of the Day of the Dead and recognized all over the world.

Maintaining harmony between the worlds of the living and the dead was a key element in the beliefs of the Aztecs, Mayans, Olmecs and other farming peoples of America before the arrival of the Europeans. Festivals in honour of the dead took place throughout the year playing an important role in maintaining social relationships. In Latin America, rituals such as renovating graves, building altars or preparing special dishes require the cooperation of family members and friends who meet and pray for the souls of the dead together, visit the altars they have prepared and share festival dishes to show respect to the dead. Another aim of these activities is to confirm collective identity and solidarity, pointing to the secular character of the tradition at the same time (Brandes, 1998a, 1998b; Marchi, 2013).

\section{RESEARCH METHODOLOGY AND RESULTS}

In 2004, the author conducted research in Łódź in order to estimate the number of people who visited selected cemeteries on $1^{\text {st }}$ November. The scale of visitors was estimated by counting those entering cemeteries at twominute intervals, every half an hour, between 6.00 and 22.00. The cemeteries considered in the study were the largest necropolises in Łódź. In 2019, the author decided to check the results of the research conducted 15 years 
earlier, using the same method. The study involved counting those who visited selected cemeteries and also inventorying cemetery surroundings. Moreover, the author used the methods of participant observation and photographic documentation. At both times the weather was comparable as it was sunny and the temperatures encouraged people to take a walk.

The comparative study concerned two cemetery complexes in Doły and Zarzewie (Fig. 1).

The history of the cemeteries in question was connected with two villages, Doły and Zarzew, which were joined to Łódź in 1906 and 1915, respectively. In 1896, in the village of Doly, a cemetery for Protestants and Catholics was created (currently St Vincent's Cemetery), and soon after that further ones for the followers of the Eastern Orthodox Church (1905), Baptists (1910) and Mariavites (1906). There was also a military cemetery (St George's Cemetery, 1910) and a burial place for Muslims and non-believers. In this way, Doły became a major necropolis in Łódź. In 1947, most of the Evangelical cemetery was replaced by the municipal cemetery. In 2003, Pentecostals gained their own burial ground. In 1886, in the village of Zarzew, St Ann's Cemetery was established (in today's Lodowa St), and in 1975 - a municipal cemetery was added. The total area of the cemeteries in Doły is 37.5 hectares and in Zarzew -29.9 hectares. Table 1 is a comparative presentation of cemeteries in Łódź, with 'Doły' and 'Zarzew' cemeteries highlighted.

In the study of visitor numbers, the author focused on establishing the number of person-entries to the cemeteries. He proposed to adopt the coefficient $\alpha$ as a multiple of cemetery entries during the day. Multipleentries to a given cemetery usually resulted from its transit location and the visitors' preference to take a shortcut on their way to a grave situated at the adjacentcemetery. They also resulted from visiting the same graves more than once during the day (Tanaś, 2008).

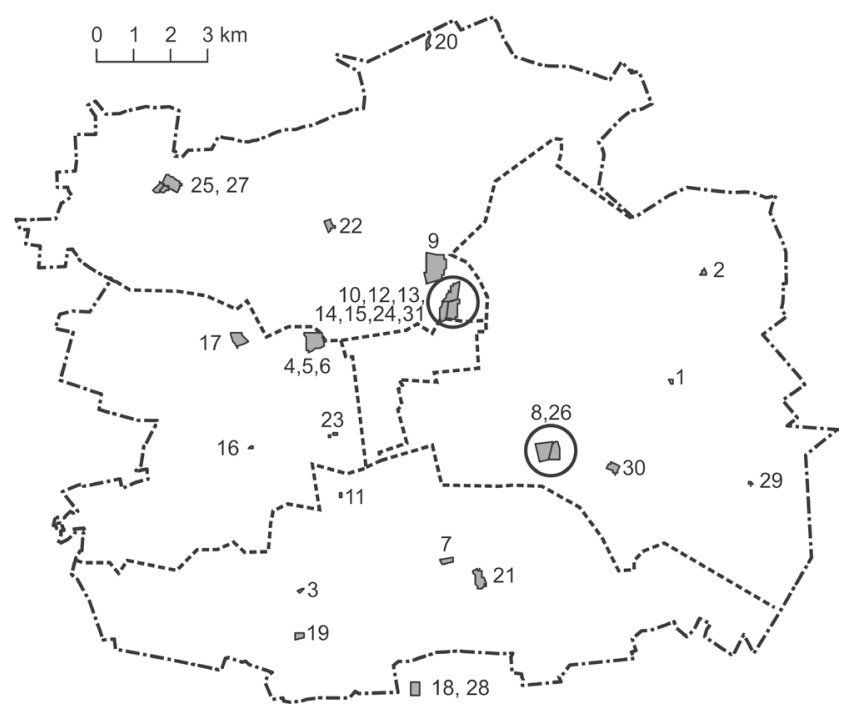

Figure 1. The distribution of cemeteries in Łódź in 2005

1 - 'Mileszki'" (St Dorothea and John the Baptist Cemetery, Catholic) - Frezjowa St, 2 - 'Nowosolna' (St Andrew Bobola Cemetery, Catholic)-KasprowiczaSt, 3-'Sopocka' (Evangelical) - Sopocka St, 4, 5, 6 - 'Old Cemetery' (St Joseph's Cemetery, Catholic, Evangelical, Eastern Orthodox ) - Ogrodowa St, 7 - 'Rzgowska' (St Francis, Catholic) - Rzgowska St, 8, 26 - 'Zarzew' (St Ann's Cemetery, Catholic, municipal) - Lodowa, Przybyszewskiego Sts, 9 - 'Bracka' (Jewish) - Bracka St, 11 - 'Piękna' (Evangelical Reformed) - Piękna St, 10, 12, 13, 14, 15, 24, 31 - 'Doły' (St Vincent's Cemetery, Catholic; St George Cemetery, military, municipal, Eastern Orthodox, Mariavite, Baptist, Catholic, Pentecostal) - Wojska Polskiego, Smutna, Telefoniczna Sts, 16 - 'Retkinia' (Catholic) - Retkińska St, 17 - 'Mania' (St Anthony, Catholic)-SolecSt, 8, 18, 28-'Starowa Góra' (St Maximilian Kolbe war cemetery, Catholic), 19 - 'Ruda' (Catholic) - Mierzejowa St, 20 - 'Łagiewniki' (Catholic), 21 - 'Kurczaki' (St Adalbert Cemetery, Catholic) - Kurczaki St, 22 - 'Radogoszcz' (Catholic) - Zgierska St, 23 - 'Poniatowski Park' (war cemetery) - Żeromskiego St, 25, 27 - 'Szczecińska' (Our Lady of Perpetual Help Cemetery, Catholic, municipal) - Szczecińska St, 29 - 'Andrzejów' (Our Lady of the Immaculate Conception Cemetery, Catholic), 30 - 'Zakładowa' (Catholic) - Zakładowa St

Source: author

Table 1. Cemeteries in Łódź

\begin{tabular}{|l|c|c|}
\multicolumn{1}{|c|}{ Cemetery } & Founded & $\begin{array}{c}\text { Area } \\
\text { (ha) }\end{array}$ \\
\hline St Dorothea and John the Baptist - Mileszki & $19^{\text {th }} \mathrm{c}$ & 1.0 \\
\hline St Andrew Bobola - Nowosolna & 1846 & 2.0 \\
\hline Evangelical - Sopocka St & 1850 & 1.1 \\
\hline St Joseph - Ogrodowa St & 1855 & 10.6 \\
\hline Eastern Orthodox - Srebrzyńska St & 1855 & 0.7 \\
\hline Evangelical - Ogrodowa St & 1855 & 9.5 \\
\hline St Francis - Rzgowska St & 1882 & 4.8 \\
\hline St Ann - Lodowa St (Zarzew) & 1886 & 18.5 \\
\hline Jewish - Bracka St & 1892 & 42.0 \\
\hline St Vincent - Smutna St (Doły) & 1896 & 17.0 \\
\hline Evangelical Reformed - Piękna St & 1904 & 0.6 \\
\hline
\end{tabular}


Table 1. Cemeteries in Łódź

\begin{tabular}{|c|c|c|}
\hline Cemetery & Founded & $\begin{array}{c}\text { Area } \\
\text { (ha) }\end{array}$ \\
\hline Eastern Orthodox - Telefoniczna St (Doły) & 1905 & 1.9 \\
\hline Mariavite - Wojska Polskiego St (Doły) & 1906 & 0.8 \\
\hline St George - Wojska Polskiego St (Doły) & 1910 & 2.7 \\
\hline Baptist - Telefoniczna St (Doły) & 1910 & 1.5 \\
\hline Retkinia parish cemetery - Retkińska St & 1913 & 1.0 \\
\hline St Anthony - Solec St (Mania) & 1914 & 11.0 \\
\hline World War I cemetery - Gadka Stara & 1914 & 5.2 \\
\hline Ruda parish cemetery - Mierzejowa St & 1917 & 3.3 \\
\hline Łagiewniki parish cemetery - Okólna St & 1918 & 1.1 \\
\hline St Adalbert - Kurczaki St & 1924 & 15.0 \\
\hline St Roch - Zgierska St (Radogoszcz) & 1925 & 5.5 \\
\hline World War II cemetery -Józef Poniatowski Park & 1945 & 0.3 \\
\hline Municipal cemetery - Smutna St (Doły) & 1947 & 12.0 \\
\hline Our Lady of Perpetual Help- Szczecińska St & 1949 & 22.0 \\
\hline Municipal cemetery - Przybyszewskiego St (Zarzew) & 1975 & 11.4 \\
\hline Municipal cemetery - Hodowlana St (Szczecińska) & 1988 & 5.6 \\
\hline St Maria Kolbe - Gadka Stara & 1991 & 5.5 \\
\hline Our Lady of Immaculate Conception- Andrzejów & 1992 & 2.9 \\
\hline All Saints - Zakładowa St & 2000 & 7.0 \\
\hline Pentecostals - Smutna St (Doły) & 2003 & 2.5 \\
\hline
\end{tabular}

Source: author based on data provided by the cemetery administration and the Provincial Monument Conservation Office.

Table 2. The number of person-entries to the cemeteries in question on $1^{\text {st }}$ November 2004 and $1^{\text {st }}$ November 2019

\begin{tabular}{|l|c|c|c|c|c|c|c|}
\hline \multirow{3}{*}{ Cemetery } & \multirow{2}{*}{$\begin{array}{c}\text { Cemetery area } \\
\text { (ha) }\end{array}$} & \multicolumn{6}{|c|}{ Multiple entries to cemeteries $(\alpha)$ in thousands } \\
\cline { 3 - 9 } & & \multicolumn{2}{|c|}{1} & \multicolumn{2}{|c|}{1.5} & \multicolumn{2}{|c|}{2} \\
\cline { 3 - 8 } & & 2004 & 2019 & 2004 & 2019 & 2004 & 2019 \\
\hline Doły & 37.6 & 270.0 & 264.0 & 180.0 & 176.0 & 135.0 & 132.0 \\
\hline Zarzew & 29.9 & 203.0 & 162.0 & 135.3 & 108.0 & 101.5 & 81.0 \\
\hline
\end{tabular}

Source: author based on Tanaś (2008).

In the author's opinion, based on the observation of visitors at Łódź cemeteries in 2004, 2005 and 2009, coefficient $\alpha$ falls into the range of 1.5 to 2 . This means that the visitors entered the cemetery 1.5-2 times during the day, on average (they visited the cemetery once, twice or several times a day). In the case of the cemeteries in question, coefficient $\alpha$ was rated at 1.5 (Table 2).

Doły cemeteries are located in the northern part of the city. In 2004, about 27,000 people entered the cemeteries at the peak of the visits (10.00-12.00), and in 2019 - about 26,500. In 2004, about 270,000 person-entries were recorded at seven cemeteries in Doły, during the whole day (6.00-10.00), and in $2019-264,000$. The number of person entries over a period of 15 years had decreased only by $3 \%$. At $\alpha=1.5$, on $1^{\text {st }}$ November, the Doły cemeteries were visited by ca. 180,000 people in 2004 and by 176,000 in 2019. The results are then highly comparable, allowing for a statistical error of $3-5 \%$.

Zarzew cemeteries are located in the south-east part of the city, close to Widzew a large housing estate. At the peak of the visits (10.00-12.00) in 2004, about 22,000 people entered the cemeteries within one hour, and in 2019 - about 18,000 , which was a decrease by about $20 \%$ over the period of 15 years. Jointly, at the Zarzew cemeteries, about 203,000 entries were recorded on All Saints' Day (6.00-10.00), while in 2019 it was 162,000. Thus, the number of person-entries decreased by about $20 \%$ over a period of 15 years. At $\alpha=1.5$, on $1^{\text {st }}$ November, 
the Zarzew cemeteries were visited by ca. 135,000 people in 2004 and 108,000 people in 2019.

All together, in 2004, the cemeteries in question (at $\alpha=1.5$ ) were visited by about 315,000 people, and in 2019 by 284,000 , which was a decrease by about $10 \%$. It should be noted that in 2004, Łódź was inhabited by 774,000 and in 2019 by only slightly over 685,000 , which means that Łódź's population had decreased by $11.5 \%$ between 2004 and 2019.

In 2004, the author conducted research on the main motivations to visit cemeteries on 1st November ${ }^{2}$. This showed that in Doly cemeteries, $8 \%$ of the respondents indicated a walk (3\%) and a cognitive motivation $(5 \%)$, while in the Zarzew cemeteries, similar declarations were made by $7 \%$ of the respondents ( $5 \%$ and $2 \%$, respectively). These were people who did not have relatives or friends buried at those cemeteries. The differences were small, but cognitive motivation was more common in Doły, probably due to the fact that the graves of distinguished inhabitants are located at municipal and military cemeteries. For comparison, at the historical Old Cemetery in Ogrodowa St, a walk for recreational and cognitive purposes on that day was indicated by $12 \%$ of the respondents who were not visiting the graves of their family members or friends. The results of the study clearly point to the tradition of recreational walks and the exceptional atmo sphere at cemeteries at that time as motivations to visit them.

Apart from verifying the number of people visiting cemeteries in 2004 and 2019, the author also conducted an inventory of the retail outlets and food kiosks located near the cemeteries in question. The number of stalls may point to the role of trade and gastronomy on All Saints' Day both for traders and inhabitants and most sold flowers, grave candles or decorative elements (including devotional items). The visitors were interested in the food kiosks which offered hot dishes, grilled oscypki (smoked cheese made from sheep milk), hamburgers, hot dogs, ice creams, candy floss, cakes and bagels a traditional specialty on All Saints' Day. Stalls where you could buy toys and balloons provoked various comments. Participant observation, particularly in Smutna St in Doły and Przybyszewskiego St in Zarzew, allowed the author to experience the noise, the festival atmosphere, the smell of fried food, and the sight of children with balloons, eating candy floss and icecream. This clearly suggests the country fair character of the festivity, with its atmosphere of a parish church fair or festival.

Although the atmosphere of a country fair and a church fair felt around the cemeteries sometimes provoked behaviour and comments suggesting disapproval of the food and toy stalls, the author believes that they were generally accepted. It should be stressed that eating the food sold from the stalls was not observed inside the cemeteries, contrary to cigarette smoking.

In the peak hours at the cemetery in Lodowa Street, a musician playing the violin and using portable loudspeakers was heard, and in the complex of Zarzew cemeteries (Lodowa, Przybyszewskiego and Smutna Sts) five beggars were observed.

The cemeteries in Doły were surrounded by 230 retail outlets selling flowers, grave candles and decorations, including eight stands selling toys, balloons and devotional objects, as well as 30 food stalls offering hot dishes, bread, hot dogs, warmed oscypki, popcorn, candy floss, ice cream and bagels (7) (Fig. 2). For comparison, on three Sundays in May 2020, an average of 22 retail outlets were recorded including 10 permanent shops and 12 temporary stalls selling flowers, candles and decorations.

The Zarzew cemeteries were surrounded by 229 retail outlets selling flowers, grave candles or decorations, including six selling toys, balloons and devotional

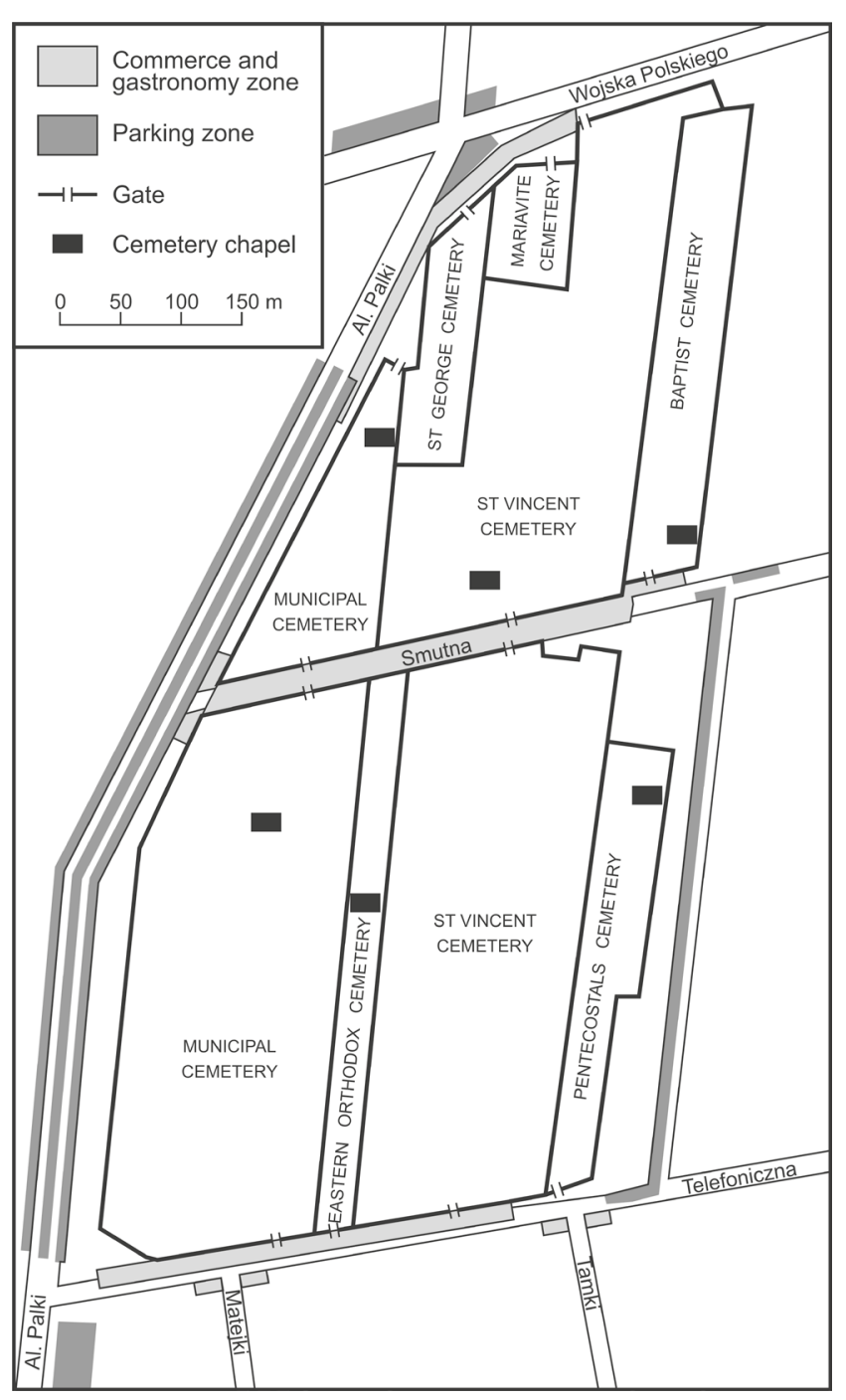

Figure 2. The development of 'Doły' cemeteries surroundings Source: author 
objects, as well as 18 food stalls offering hot dishes, bread, hot dogs, warmed oscypki, popcorn, candy floss, ice cream and bagels (7) (Fig. 3). For comparison, on three Sundays in May 2020, 12 permanent shops and 8 temporary stalls selling only flowers, candles and decoration articles were recorded (20 retail points, jointly). There were no food stalls.

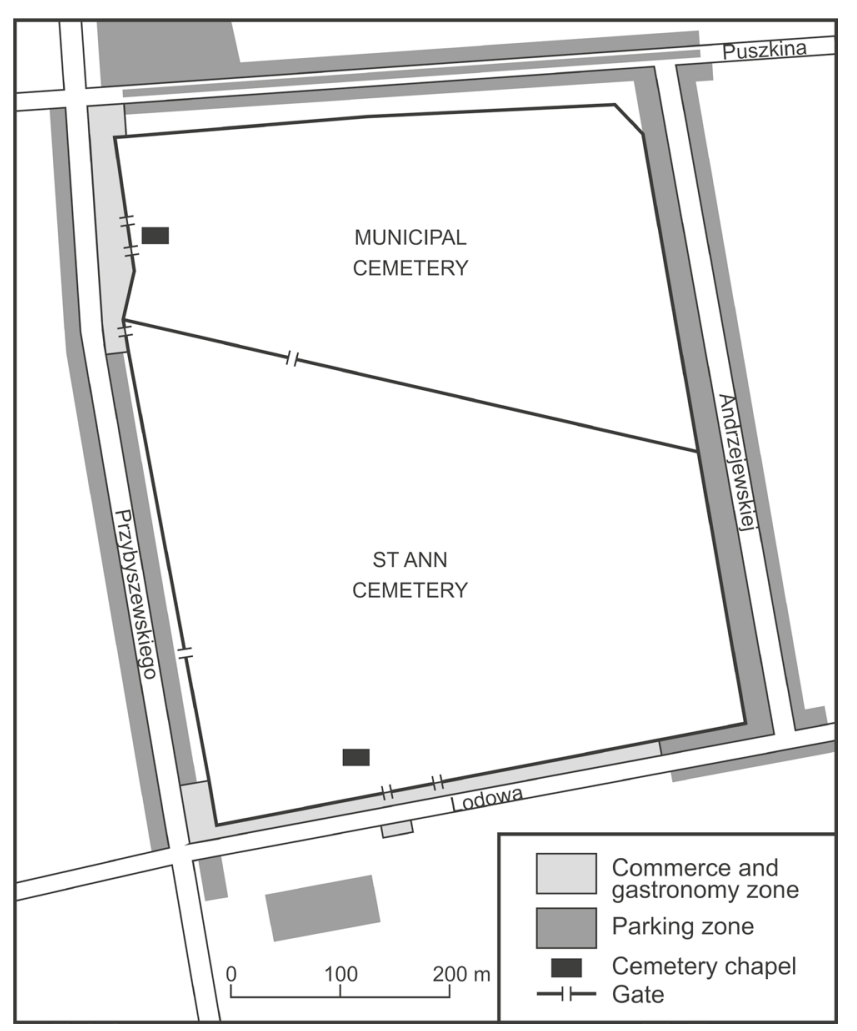

Figure 3. The development of 'Zarzew' cemeteries surroundings Source: author

At the car parks in the streets adjacent to the Zarzew cemeteries (Lodowa, Przybyszewskiego, Puszkina and Andrzejewska Sts), about 3000 cars were parked in the 10.00-12.00 period.

Comparing the number of retail and food outlets offering their services around both cemetery complexes on $1^{\text {st }}$ November and on a Sunday in May, 10 times more facilities were available on All Saints' Day than in May.

The research conducted by the author in 2005 shows that about $85 \%$ of adult respondents visited the cemetery at least once on All Saints' Day. In Poland, on $1^{\text {st }}$ and $2^{\text {nd }}$ November, cemeteries and graves are visited not only out of the sense of religious, civil or family duty, but they are also a place of cognitive and recreational walks taken by people in their free time. This issue has been presented in the author's study regarding motivations for cemetery visits (Tanaś, 2008; see also: Kulczyńska, Marciniak, 2018).

\section{SUMMARY}

Nowadays, the character of the November festival in honour of the dead is a consequence of cultural diffusion, i.e. the distribution of cultural elements by way of borrowing which results in their cultural syncretism. The author has tried to show that although the nature of All Saints' Day in Poland and the Day of the Dead in Latin America is different, both festivals share a number of features.

Globalization, the commonality of information distribution, the development of mass culture and the influence of other cultures on Polish customs certainly have caused a growing secularization and commercialization of All Saints' Day.

All Saints' Day is a Christian Church festival, celebrated by all its denominations, though it does not always include the tradition of visiting graves. The atmosphere of this day and the power of tradition are shared by the majority of Polish society, believers and non-believers alike. In the era of developing global communication and commercialization of life, the character of the festival in honour of the dead is constantly changing.

It should be remembered that All Saints' Day is the most important day in the process of promoting the educational function of cemeteries, developing cultural awareness, building local communities and the sense of civic ties based on respect for ancestors and history. While the festival lasts, necropolises are the focus for media attention, a place for walks, family and patriotic education, as well as a cultural tourism destination. A significant role in preserving the artistic and historical heritage of Polish cemeteries is played by charity collections as money that is raised at cemeteries on All Saints' Day is used for preserving historical monuments. This type of charity collection was started by Jerzy Waldorf, who founded the Social Protection Committee for the Preservation of Old Powązki in 1974 and initiated the tradition of the $1^{\text {st }}$ November collections.

The pop-culturization of All Saints' Day is a fact. A change in motivations to visit cemeteries at the beginning of November is strictly connected with socioeconomic and cultural transformations including growing social secularization. Visiting a cemetery displays the features of a country fair, cultural globalization and commercialization, or even a fete. This confirms the thesis that, like the Mexican Day of the Dead, Polish All Saints' Day can be treated as a cultural tourism product.

The author has tried to present the social significance of cemeteries, focusing not only on religious but also secular values, including the underestimated therapeutic and regenerative function of cemeteries, as well as their role in shaping valued community attitudes such as patriotism and citizenship. The social function performed 
by cemeteries is particularly visible at the beginning of November both in Poland and in Latin America. Despite the fact that the ideology of the cult of the dead, both in sacred and profane spheres, undergoes constant cultural change, the mass character of visiting graves on All Saints' Day in Poland and on the Day of the Dead in Latin America proves the significance and need for strengthening local social ties e.g. building up religious, family and civil communities based on the memory of the deceased. In this context, the assets of cemeteries and the cult of the dead may be a significant component of the cultural tourism product.

\section{ENDNOTES}

\begin{abstract}
${ }^{1}$ One of the first works dedicated to cemetery planning, cited later by many authors, is that by Loudon (1843), broadly described by Curl (1980) in A Celebration of death. Curl analyses the idea of a "cemetery garden" conceived by Loudon, a Scottish botanist, and doyen of the British school of landscape design. Studies on the evolution of cemetery architectonic designs have been conducted by Etlin (1984) and Ragon (1983), among others.

${ }^{2}$ So far unpublished research results. Data was collected during the survey by the students of the Theological Seminary in Łódź during a charity collection organized on 31 October and 1 November 2004, at the cemeteries in question.
\end{abstract}

\section{REFERENCES}

Ariés, Ph. (1989). Człowiek i śmierć. Warsaw: Państwowy Instytut Wydawniczy.

Brandes, S. (1998a). The Day of the Dead, Halloween, and the quest for Mexican national identity. The Journal of American Folklore, 111 (442), 359-380.

Brandes, S. (1998b). Iconography in Mexico's Day of the Dead: Origins and meaning. Ethnohistory, 45 (2), 181-218.

Cano, L.M., Mysyk, A. (2004). Cultural tourism. The state and Day of the Dead. Annals for Tourism Research, 31 (4), 879-898.

Curl, J.S. (1980). A celebration of death. London: Constable.
Długozima, A. (2011). Cmentarze jako ogrody żywych i umarlych. Warsaw: Wydawnictwo Sztuka ogrodu, Sztuka krajobrazu Beata Gawryszewska.

Eliade, M. (1996). Sacrum i profanum. O istocie religijności. Warsaw: Wydawnictwo KR.

Etlin, R.E. (1984). The architecture of death the transformation of the cemetery in eighteenth-century Paris. London: MIT Press, Cambridge, Massachusetts.

Jackowski, A. (2003). Święta przestrzeń świata. Podstawy geografii religii. Cracow: Wydawnictwo UJ.

Jaszczak, A., Dreksler, B. (2013). Cmentarze - miejsca pamięci, tradycji i religii. Cmentarze i ogrody w krajobrazie. O sacrum, symbolice, kompozycji i przemijaniu. Prace Komisji Krajobrazu Kulturowego, 22, 31-39.

Kolbuszewski, J. (1985). Wiersze z cmentarza. O wspótczesnej epigrafice wierszowanej. Warsaw: Polskie Towarzystwo Ludoznawcze.

Kolbuszewski, J. (1996). Cmentarze. Wrocław: Wydawnictwo Dolnośląskie.

Kulczyńska, K., Marciniak, N. (2018). Odwiedzenia nekropolii na Miłostowie w Poznaniu i ich motywy. Rozwój Regionalny i Polityka Regionalna, 44, 205-219.

Kupisiński, Z. (2007). Śmierć jako wydarzenie eschatyczne. Lublin: Wydawnictwo KUL.

Lewandowski, R. (2003). Idea śmierci w kontekście Święta Zmarłych. Anthropos? 1, 54-85

Loudon, C.J. (1843). On the laying out, planting and managing of cemeteries and on the improvement of churchyards. London: [b.w.].

Marchi, R. (2013). Hybridity and authenticity in US Day of the Dead celebrations. Journal of American Folklore, 126 (501), 272-301.

Miller, M.S., Space, J.D. (2006). Hallowed ground, place, and culture: The cemetery and the creation of place. Space and Culture, 9 (4), 334-350.

Ragon, M. (1983). The space of death. A study of funerary architecture, decoration, and urbanism. Charlottesville: University Press of Virginia.

Stasiak, A., Tanaś, S. (2005). Przestrzeń sepulkralna w turystyce. Turystyka i Hotelarstwo, 8, 9-42.

Tanaś, S. (2008). Przestrzeń turystyczna cmentarzy. Wstęp do tanatoturystyki. Łódź: Wydawnictwo Uniwersytetu Łódzkiego.

Article received:

24 June 2020

Accpeted:

9 December 2020 